\title{
PENGARUH MODEL PEMBELAJARAN PROBLEM BASED LEARNING TERHADAP KETERAMPILAN BERPIKIR KRITIS
}

\author{
Ida marhamah', Yahdi', Siti Hajaroh' \\ ${ }^{1}$ Tadris Kimia, FTK UIN Mataram, Mataram.Email: \\ yahdi8o@uinmataram.ac.id
}

\section{ABSTRAK}

Penelitian ini bertujuan untuk mengetahui apakah ada pengaruh model pembelajaran problem based learning terhadap keterampilan berpikir kritis siswa kelas XI IPA SMAN 1 Praya Barat Daya Tahun Pelajaran 2018/2019. Jenis penelitian yang digunakan adalah penelitian kuantitatif dengan metode quasi eksperimen, pengambilan sampel penelitian dilakukan dengan tehnik sampling jenuh. Instrumen yang digunakan untuk pengumpulan data adalah tes essay. Tehnik analisis data yang digunakan adalah uji-t test menggunakan SPSS16,o for windows, sebagai persyaratan analisis dilakukan uji normalitas dan uji homogenitas. Dari hasil penelitian yang dilakukan di SMAN 1 Praya Barat Daya terdapat pengaruh model pembelajaran problem based learning terhadap keterampilan berpikir kritis siswa pada materi larutan penyangga, dengan nilai signifikan 0,00 < 0,05 maka dapat disimpulkan bahwa ada pengaruh yang signifikan model pembelajaran problem based learning terhadap keterampilan berpikir kritis siswa kelas XI IPA SMAN 1 Praya Barat Daya Tahun Pelajaran 2018/2019, hal ini terbukti bahwa perlakuan yang berbeda akan mendapatkan hasil yang berbeda pula.

KATA KUNCI: model pembelajaran problem based learning, keterampilan berpikir kritis.

\section{PENDAHULUAN}

Pesatnya perkembangan dunia global menuntut kesiapan bagi bangsa Indonesia untuk membentuk generasi muda penerus bangsa yang memiliki dedikasi tinggi serta 
kepribadian yang kompetitif untuk meningkatkan kualitas hidup bangsanya demi Indonesia yang lebih baik. Kunci dari cita-cita untuk mewujudkan Indonesia yang mampu bersaing dalam dunia global adalah sistem pendidikan yang berkualitas dimana sistem tersebut dapat mencetak sumber daya manusia yang unggul (Sugiyono, 2017).

Menurut Undang-undang No 20 Tahun 2003 pasal 1 Pendidikan adalah usaha sadar dan terencana untuk mewujudkan suasana belajar dan proses pembelajaran agar peserta didik secara aktif mengembangkan potensi dirinya untuk memiliki kekuatan spiritual keagamaan, pengendalian diri, kepribadian, kecerdasan, akhlak mulia, serta keterampilan yang diperlukan dirinya, masyarakat, bangsa dan negara. Oleh karena itu faktor yang sangat mempengaruhi terbentuknya peserta didik yang secara aktif mampu mengembangkan potensi dirinya adalah kemampuan satuan pendidikan dalam mengelola proses pembelajaran yang bermakna.

Kemampuan berpikir kritis menurut Scriven dan Paul dalam Santrock (2015) didefinisikan bahwa berpikir kritis adalah proses disiplin yang secara intelektual aktif dan terampil mengkonseptualisasi, menerapkan, menganalisis, mensistesis, dan mengevaluasi informasi yang dikumpulkan lewat pengamatan, pengalaman, refleksi, penalaran, atau komunikasi sebagai panduan untuk kepercayaan dan tindakan.

Berdasarkan hasil observasi awal yang dilakukan peneliti pada hari sabtu 26 januari 2019 di kelas XI IPA SMAN 
1 Praya Barat Daya dengan guru mata pelajaran kimia menyatakan bahwa kemampuan berpikir kritis siswa masih kurang disebabkan karena pemahaman dan keaktifan siswa masih rendah, siswa masih bayak yang kurang aktif ketika proses belajar berlangsung. Hal tersebut akan mempengaruhi keterampilan berpikir kritis siswa sehingga' masih banyak siswa yang mendapat nilai di bawah KKM. Hal ini terlihat dari kurangnya keaktifan siswa dalam mengajukan pertayaan dan memberikan tanggapan sehingga nilai ratarata siswa dalam kemampuan berpikir kritis kelas XI IPA adalah $60,38 \%$.

Ada beberapa faktor yang mempengaruhi keterampilan berpikir kritis siswa rendah, yaitu guru masih menggunakan model pembelajaran yang monoton, artinya siswa hanya mencatat dan mendengarkan penjelasan dari guru tersebut. Guru tidak memanfaatkan model-model pembelajaran yang menarik dan membuat siswa tidak cepat bosan. Dalam hal ini khususnya guru mata pelajaran perlu mencari dan menerapkan suatu model pembelajaran yang menarik agar dapat membantu siswa memahami dan mampu mengubah keterampilan berpikir kritis siswa menjadi lebih tinggi.

Salah satu alternatif yang dapat membuat siswa berpikir kritis dan merubah pola pikir kritis siswa adalah guru harus memilih model pembelajaran yang ideal. Model pembelajaran yang ideal yaitu model pembelajaran kooperatif. Model pembelajaran kooperatif merupakan strategi pembelajaran yang menempatkan siswa 
berkelompok, yang beranggotakan 4-6 orang dengan tingkat kemampuan dan jenis kelamin yang berbeda-beda (Bahtiar, 2015).

Model pembelajaran kooperatif yang dianggap cocok diterapkan yaitu model pembelajaran Probel Based Learning (PBL), model pembelajaran Probel Based Learning adalah model pembelajaran berbasis masalah merupakan model pembelajaran yang di dalamnya terdapat rangkaian aktivitas yang dilakukan baik secara kelompok atau secaraa individual dalam memecahkan suatu permasalan yang berkaitan dengan dunia nyata yang menuntut siswa untuk berpikir, berkomunikasi, mencari dan meyelesaikan masalah dengan berpikir secara ilmiah (Suprihatiningrum, 2016). Tujuan umum dari model pembelajaran problem based learning yakni mengajak siswa semakin berani dan kreatif dalam berimajinasi dan dengan imajinasinya siswa dibimbing untuk menciptakan penemuan-penemuan, baik yang berupa penyempurnaan yang telah ada maupun menciptakan ide atau gagasan yang baru (Suprihatiningrum, 2016).

Keunggulan dari model pembelajaran problem based learning ini yaitu dapat membuat siswa berpikir kritis, karena siswa dituntut untuk bisa merumuskan sendiri suatu permasalahan kemudian mengumpulkan data yang mereka dapatkan. Selanjutnya siswa membuat hipotesis dan kesimpulan. Sehingga model Probel Based Learning dianggap dapat meningkatkan kemampuan berpikir kritis siswa.

Dari latar belakang di atas, inilah yang menjadi dasar dalam penelitian ini sehingga penulis melakukan penelitian 
tentang pengaruh model pembelajaran problem based learning terhadap kemampuan berpikir kritis siswa kelas XI IPA SMAN 1 Praya Barat Daya tahun pelajaran 2018/2019”.

\section{METODE PENELITIAN}

Penelitian ini merupakan penelitian kuantitatif menggunakan metode quasi eksperimen. Tehnik pengambilan sampel pada penelitian ini yaitu menggunakan tehnik sampling jenuh. Populasi dan sampel dalam penelitian ini yaitu semua siswa kelas XI IPA SMAN 1 Praya Barat Daya. Penelitian ini dilakukan di kelas XI IPA SMAN 1 Praya Barat Daya pada bulan April sampai bulan mei pada semester genap tahun pelajaran 2018/2019.

Variabel dalam penelitian ini ada dua yaitu variabel bebas dan variabel terikat. variabel bebas adalah model pembelajaran problem based learning dan variabel terikat yang digunakan yaitu keterampilan berpikir kritis. Desain dalam penelitian ini menggunakan metode quasi eksperimen karena guru tidak mampu mengontrol kegiatan siswa selama 24 jam. Desain penelitian yang digunakan adalah one-group pretest-postet design.

$\mathrm{O}_{1} \times \mathrm{O}_{2}$

Keterangan

$\mathrm{O} 1$ = nilai pretest (sebelum diberi perlakuan)

$\mathrm{O} 2$ = nilai postest (setelah diberikan perlakuan)

Instrumen dalam penelitian ini menggunakan tes yang berbentuk essay. Tes essay ini dibuat sesuai dengan indikator 
berpikir kritis. Tehnik pengumpulan data pada penelitian ini menggunakan tes uraian. Tes uraian ini diberikan sebelum dan sesudah menggunakan model pembelajaran problembased learning atau disebut dengan pretest dan posttest.

Teknik analisis data dilakukan dengan menguji validitas suatu soal yang akan digunakan, dimana penelitian ini menggunakan validitas kontruk atau validitas ahli, sehingga validator yang peneliti pakai yaitu dosen tetap yang berada pada bidang kimia yaitu ibu Raehanah M,Pd. Selanjutnya yaitu uji prasyarat suatu instrumen yaitu menggunakan uji normalitas dan uji homgenitas. Uji normalitas dan uji homogenitas ini dilakukan menggunakan spss 16,0 for windows. Kemudian untuk uji hipotesis menggunakan uji $\mathrm{t}$ jika sampel yang didapatkan bernilai normal dan homogen, uji t ini dicari menggunakan analisis spss.

\section{HASIL DAN PEMBAHASAN}

\section{HASIL PENELITIAN}

Secara umum hasil penelitian yang dideskripsikan pada bagian ini yaitu skor nilai keterampilan berpikir kritis siswa sebelum dan sesudah diberikan perlakuan menggunakan model pembelajaran problem based learning. 
Tabel 1. Deskripsi Nilai Rata-Rata Sebelum dan Sesudah Diberikan Perlakuan.

\begin{tabular}{|c|r|r|}
\hline Deskripsi & \multicolumn{1}{|c|}{ Nilai pretest } & \multicolumn{1}{|c|}{ Nilai postest } \\
\hline Jumlah nilai & 2056 & 2764 \\
\hline Nilai maksimum & 76 & 96 \\
\hline Nilai minimum & 32 & 44 \\
\hline Nilai rata-rata & 52,72 & 70,87 \\
\hline
\end{tabular}

Data yang diperoleh yaitu skor kemampuan berpikir kriti siswa pada materi larutan penyangga, data ini diperoleh dari pretes dan postest. Skor pretest yang dihitung dari 39 sampel memiliki nilai tertinggi pada pretest berpikir kritis sebesar 76 dan nilai terendahnya 32. Pada posttest berpikir kritis nilai tertinggi sebesar 96 dan nilai terendahnya 44 . Jumlah nilai rata-rata sebelum dan sesudah melakukan perlakuan berbanding $10 \%$. Nilai rata-rata sebelum diberi perlakuan yaitu 52.71 dan jumlah rata-rata setelah diberi perlakuan yaitu 70.87 .

\section{Tabel 2. Hasil Uji Normalitas}

\begin{tabular}{|c|r|r|r|r|r|r|}
\hline \multirow{2}{*}{ Kelompok } & \multicolumn{3}{|c|}{ Kolmogorov-Smirnov $^{\mathbf{a}}$} & \multicolumn{3}{c|}{ Shapiro-Wilk } \\
\cline { 2 - 7 } & Statistic & df & Sig. & Statistic & df & \multicolumn{1}{c|}{ Sig. } \\
\hline KELAS A & .123 & 39 & .141 & .954 & 39 & .111 \\
\hline KELAS B & .126 & 39 & .123 & .929 & 39 & .016 \\
\hline
\end{tabular}

Berdasarkan tabel diatas nilai sig untuk kelas A (postest) yaitu 0,14 >0,05 dan untuk kelas B (pretest) yaitu $0,12>0,05$ artinya data berdistribusi normal. Karena data yang didapatkan berdistribusi normal sehingga untuk uji 
hipotesis digunakan uji-t test dengan menggunakan analisis SPSS 16,0 for windows.

Table 3. Uji Homogenitas Keterampilan Berpikir Kritis

\begin{tabular}{|c|c|c|c|}
\hline Levene Statistic & df1 & $\mathrm{df}_{2}$ & Sig. \\
\hline .804 & 1 & 76 & .373 \\
\hline
\end{tabular}

Berdasarkan tabel di atas nilai sig 0,37 > 0,05 artinya data berdistribusi homogen. Karena data yang didapatkan berdistribusi homogen sehingga untuk uji hipotesis digunakan uji-t test dengan menggunakan analisis SPSS 16,0 for windows.

Table 4. Uji t-testPaired Samples Test

\begin{tabular}{|c|c|c|c|c|c|c|c|}
\hline \multicolumn{5}{|c|}{ Paired Differences } & \multirow[t]{2}{*}{$T$} & \multirow[t]{2}{*}{ df } & \multirow{2}{*}{$\begin{array}{l}\text { Sig. (2- } \\
\text { tailed) }\end{array}$} \\
\hline \multirow[t]{2}{*}{ Mean } & \multirow[t]{2}{*}{$\begin{array}{l}\text { Std. } \\
\text { Deviat } \\
\text { ion }\end{array}$} & \multirow[t]{2}{*}{$\begin{array}{l}\text { Std. } \\
\text { Error } \\
\text { Mean }\end{array}$} & \multicolumn{2}{|c|}{$\begin{array}{l}95 \% \text { Confidence } \\
\text { Interval of the } \\
\text { Difference }\end{array}$} & & & \\
\hline & & & Lower & Upper & & & \\
\hline 18.154 & 12.443 & 1.992 & 14.120 & 22.187 & 9.112 & 38 & .000 \\
\hline
\end{tabular}

Berdasarkan nilai sig yang didapatkan yaitu 0,00 < 0,05 artinya hipotesis dalam penelitian ini diterima. Artinya ada pengaruh model pembelajaran problem based learning terhadap keterampilan berpikir kritis siswa. 


\section{PEMBAHASAN}

Penelitian ini bertujuan untuk mengetahui keterampilan berpikir kritis siswa pada sub materi larutan penyangga, dimana penelitian ini dilakukan di kelas XI IPA SMAN 1 Praya Barat Daya untuk mengetahui ada atau tidaknya keterampilan berpikir kritis siswa sebelum dan sesudah diberikan perlakuan menggunakan model pembelajaran problembased learning. Penggunaan model pembelajaran problem based learning ini diyakini dapat berpengaruh positif terhadap keterampilan berpikir kritis siswa.

Hasil identifikasi masalah menunjukkan keterampilan berpikir kritis siswa masih rendah dilihat dari hasil observasi awal. Hasil observasi menunjukkan bahwa ketika proses pembelajaran berlangsung guru masih menggunakan model pembelajaran yang monoton, sehingga siswa tidak aktif ketika proses belajar mengajar berlangsung. Kurangnya kreatifitas guru untuk mengubah model pembelajaran menyebabkan keterampilan berpikir kritis siswa rendah. Model pembelajaran yang baru dan menarik bisa mengubah cara berpikir dan keaktifan siswa dalam proses pembelajaran, model pembelajaran problem based learning adalah model pembelajaran yang menuntut keaktifan siswa dalam proses belajar mengajar, sehingga bukan hanya guru yang aktif di dalam kelas.

Menurut Arends dan Jamil dalam Anam (2016), pembelajaran problem based learning adalah model pembelajaran ini mendorong siswa mampu mandiri dan 
tidak hanya mengandalkan instruksi dan bimbingan dari guru akan tetapi siswa dituntut mampu berpikir kreatif, mandiri, teliti dan mampu menemukan gagasan-gagasan atau ide-ide baru.

Dari proses pembelajaran yang dilakukan guru menggunakan model pembelajaran problem based learning dapat dikatagorikan sangat baik dilihat dari nilai rata-rata yang didapatkan oleh siswa, nilai rata-rata pada kelas sebelum diberi perlakuan yaitu 52.71 dan nilai rata-rata setelah diberi perlakuan yaitu 70.87. Dari hasil nilai rata-rata pencapaian siswa terlihat bahwa terdapat atau ada pengaruh model pembelajaran problem based learning terhadap keterampilan berpikir kritis siswa.

Berdasarkan nilai rata-rata di atas, dan pada saat melakukan penelitian pretest didapatkan hasil yang tidak maksimal, dilihat dari suasana kelas yang tidak kondusif menyebabkan siswa terlihat tidak semangat untuk belajar, sedangkan untuk penelitian postest dengan menerapkan model problem based learning didapatkan hasil yang maksimal, terlihat dari suasana kelas yang menarik membangkitkan keaktifan siswa karena dalam model problem based learning siswa dituntut belajar terlebih dahulu sebelum proses belajar mengajar berlangsung, sehingga pada saat proses pembelajaran siswa tidak hanya duduk diam saja di dalam kelas akan tetapi siswa tetap aktif selama proses belajar mengajar berlangsung.

Dalam penelitian sebelumnya yang dilakukan oleh Anas (2017) yang meneliti tentang Pengaruh Penerapan 
Model Pembelajaran Berbasis Masalah (Problem Based Learning) Terhadap Hasil Belajar Matematika Peserta Didik Kelas IV MIN Sepabatu Kecamatan Tinambung Kabupaten Polewali Mandar, menunjukkan bahwa terdapat hasil yang signifikan antara model pembelajaran sebelum menggunakan model problem based learning dan setelah menggunakan model problem based learning. Penelitian yang dilakukan oleh Anas (2017) menggunakan perangkat pembelajaran yaitu buku mata pelajaran, perangkat pembelajaran ini membantu siswa untuk mengerjakan soalsoal dengan teliti sehingga dapat meningkatkan hasil belajar siswa. Dalam penelitian ini peneliti menggunakan model problem based learning (PBL) dan menggunakan buku kimia kelas XI sebagai pedoman dalam proses pembelajaran. Peneliti membuat butir soal yang tingkat kesukarannya lebih tinggi dibandingkan soal hasil belajar. Sehingga model problem based learning yang digunakan dalam penelitian ini mempunyai kelebihan tersendiri daripada penelitian yang sebelumnya. Hal tersebut membuktikan dengan menggunakan model problem based learning sebagai model pembelajaran akan memberikan efek yang baik pada proses belajar, siswa semakin semangat, antusias dan termotivasi untuk mengikuti pembelajaran pada materi larutan peyangga.

Berdasarkan hasil penelitian yang terdahulu dan penelitian yang peneliti dapatkan, penggunaan model problem based learning ini akan lebih menjamin terjadinya pemahaman yang lebih baik terhadap isi pelajaran yang diberikan. Model problem based learning juga mampu 
membangkitkan kemampuan berpikir kritis siswa dan membawa siswa ke dalam suasana rasa senang, gembira, dan bersemangat untuk belajar. Oleh karena itu, model problem based learning layak digunakan sebagai model pembelajaran untuk mempermudah guru dalam menyampaikan materi pelajaran selama proses pembelajaran berlangsung dan sebagai pedoman dalam meningkatkan keterampilan berpikir kritis siswa.

Adapun kendala-kendala setelah diberi perlakuan yaitu, sulitnya mengubah kebiasaan belajar mengajar yang biasanya siswa hanya mendengarkan penjelasan dari guru apa adanya, kearah membiasakan diri untuk belajar mandiri dan berkelompok dengan mencari tahu sendiri informasi tentang materi yang didapatkan, kurang efisiennya waktu yang digunakan ketika proses belajar mengajar berlangsung, kemudian jika ada salah satu siswa yang tidak masuk, maka akan terjadi kurangnya anggota kelompok dari kelompok yang sudah dibagikan secara homogen. Kemudian sebelum diberi perlakuan, yaitu kurangnya perhatian siswa ketika guru menjelaskan, disini terlihat jelas bahwa masih banyak siswa yang ngobrol degan teman sebangkunya. Penggunaan model pembelajaran konvensional ini terlihat jelas bahwa yang hanya berperan aktif ketika proses pembalajaran berlangsung yaitu guru, sedangkan siswa hanya duduk diam dan mendengarkan penjelasandari guru. Hal ini mengakibatkan tidak terjadinya interaksi antara guru dengan siswa, maupun siswa dengan siswa, karena pada dasarnya model ini hanya menekankan pada keaktifan guru. 
Pembelajaran menggunakan metode ceramah atau menggunakan metode konvensional membuat siswa merasa tidak dilibatkan ketika proses belajar mengajar berlangsung. Hal ini akan menyebabkan kurangnya minat dan kreatifitas berpikir kritis siswa sehingga hasil belajar yang didapatkan oleh siswa rendah.

Sementara itu penelitian setelah diberi perlakuan (posttest) menunjukkan bahwa siswa dituntut mampu berintraksi dengan teman sebayanya dan mampu bertukar pikiran. Pada proses saling bertukar pikiran tersebut terlihat jelas bahwa mana siswa yang memiliki keterampilan berpikir kritis tinggi dan siswa yang berpikir kritis rendah. Setiap siswa dituntut mampu berpikir kritis tinggi, karena siswa dituntut memiliki tanggung jawab masing-masing. Sehingga sebelum proses pembelajaran berlangsung siswa sudah diberitahukan untuk belajar terlebih dahulu.

Berdasarkan hasil pengujian menggunakan SPSS 16,0 pengujian hipotesis menggunakan uji $t$, dinyatakan bahwa terdapat pengaruh atau ada mengaruh model pembelajaran problem based learning terhadap keterampilan berpikir kritis siswa sebelum dan setelah diberikan perlakuan. Hal ini bisa dilihat dari nilai sig yang diperoleh yaitu $0,00<0,05$, yang artinya $\mathrm{H}_{0}$ ditolak dan $\mathrm{Ha}$ diterima yang menyebabkan ada pengaruh yang signifikan model pembelajaran problem based learningterhadap keterampilan berpikir kritis siswa, maka peneliti menyatakan bahwa model pembelajaran problem based learningsangat cocok digunakan dalam 
proses pembelajaran karena dapat meningkatkan keterampilan berpikir kritis siswa.

\section{KESIMPULAN}

Berdasarkan hasil penelitian menunjukkan bahwa, nilai rata-rata sebelum mendapatkan perlakuan (pretest) yaitu 52.71795 sedangkan nilai rata-rata setelah mendapatkan perlakuan dengan penerapan model problem based learning (posttest) adalah 70.87. Kemudian hasil analisis uji hipotesis dengan SPSS16,0 menunjukkan bahwa, analisis data yang didapatkan yaitu nilai signifikasi data 0,00 < 0,05 maka dapat disimpulkan bahwa ada pengaruh yang signifikan model pembelajaran problem based learning terhadap keterampilan berpikir kritis siswa kelas XI IPA SMAN 1 Praya Barat Daya Tahun Pelajaran 2018/2019, hal ini terbukti bahwa perlakuan yang berbeda akan mendapatkan hasil yang berbeda pula.

\section{DAFTAR PUSTAKA}

Anam, K. (2016). Pembelajaran Berbasis Inkuiri: Metode dan Aplikasi. Yogyakarta: Pustaka Pelajar.

Anas, M. (2017). Pengaruh Penerapan Model Pembelajaran Berbasis Masalah (Problem Based Learning) Terhadap Hasil Belajar Matematika Peserta Didik Kelas IV MIN Sepabatu Kecamatan Tinambung Kabupaten Polewali Mandar. (Skripsi). Makassar: UIN Alauddin Makassar.

Bahtiar. (2015). StrategiMengajar Sains IPA. Mataram: Institut Agama Islam Nageri Mataram. 
Kasira Moh, Metodologi Penelitian Kualitatif- Kuantitatif, Malang : UIN Maliki Press,2008

Nana Sutresna, Kimia Untuk Sekolah Menengah Atas/Madrasah Aliyah Kelas XI Peminatan Matematika Dan Ilmu-IImu Alam, Bandung: Gravindo Media Pratama, 2016

Santrock, J. W. (2015). Educational Pysycology. Jakarta: Salimba Humanika.

Sugiyono. (2010). MetodePenelitian Pendidikan. Bandung: Alfabeta.

Sugiyono. (2017). Metode Penelitian Pendidikan (Pendekatan Kuantitatif/kualitatif, dan R\&D), Bandung: Alfabeta.

Suprihatiningrum, J. (2016). Strategi Pembelajaran: Teori \& Aplikasi. Jogjakarta: Ar-Ruz Media.

Undang-Undang Republik Indonesia No 20 Thn 2003 Tentang Sistem Pendidikan Nasional. Pasal 1 ayat 1 Tentang Pendidikan. 